\title{
Effect of different additives on the properties of alumina-spinel castables
}

\author{
(Efeito de diferentes aditivos nas propriedades de concretos \\ de alumina-espinélio)
}

\author{
M. Ghasemzadeh ${ }^{1}$, A. Nemati ${ }^{2}$ \\ ${ }^{I}$ Dept. of Materials Eng., Karaj Branch, Islamic Azad University, Karaj, Iran \\ ${ }^{2}$ School of Materials Sci. \& Eng., Sharif University of Technology, Tehran, Iran \\ ghasemzadeh@kiau.ac.ir,gh_mavad@yahoo.com
}

\begin{abstract}
Physical properties of low cement castable containing 22 wt. $\% \mathrm{Al}_{2} \mathrm{O}_{3}$-rich $\mathrm{MgO}-\mathrm{Al}_{2} \mathrm{O}_{3}$ spinel and $1.7 \mathrm{wt} . \% \mathrm{CaO}$ with addition of polyacrylates, castament FS20, TPP and citric acid were investigated. Results showed castables including castament FS20 have higher flow values and better final properties comparing with castables including Darvan 7S and TPP. Also in this study we investigated the effect of addition of microsilica up to $4 \mathrm{wt} . \%$ on the properties of aluminaspinel castables. Microsilica is the finest particles in the system and due to suitable distribution of microsilica among other particle the open porosity reduced and mechanical strength increased. Slag penetrations resistance increased with increasing microsilica addition by forming a densification layer right behind the hot face of castables in service.
\end{abstract}

Keywords: refractory castables, microsilica, alumina-spinel.

\section{Resumo}

As propriedades físicas de concretos de baixo cimento contendo 22 peso $\% \mathrm{Al}_{2} \mathrm{O}_{3}$ em espinélio $\mathrm{MgO}-\mathrm{Al}_{2} \mathrm{O}_{3}$ e 1,7 peso\% $\mathrm{CaO}$ com adição de poliacrilatos, concrtagem FS20, TPP e ácido cítrico foram estudadas. Os resultados mostram que os concretos contendo FS20 tem maiores valores de fluência e melhores propriedades finais comparando com concretos como Darvan $7 S$ e TPP. Foi também estudado o efeito da adição de microsílica até 4 peso\% nas propriedades de concretos de espinélio-alumina. Microsílica é a partícula mais fina no sistema e, devido à distribuição adequada de microsílica entre as outras partículas, a porosidade aberta foi reduzida e a resistência mecânica aumentou. A resistência à penetração de escória aumentou com o aumento da adição de microsilica formando uma camada de densificação logo atrás da face quente dos concretos em uso.

Palavras-chave: concretos refratários, microsílica, espinélio-alumina.

\section{INTRODUCTION}

In recent years, monolithic refractories are replacing traditional refractory bricks in many steel making applications such as the EAF (electronic arc furnace) roof [1]. Castables should be used in the electronic arc furnace roof which cover various requirements such as cyclic thermal treatment, high temperature, and corrosion by slag and smoke respectively. The alumina-spinel castables show good properties such as high modulus of rupture, low porosity, high density, good resistance to thermal sock, high refractoriness and good resistance to slag penetration and corrosion. Another most important factor of castables is flowability that affects casting properties of the system and makes them suitable to fill complex molds and give good final properties. The production of highly fluid castables depends on the particle size distribution and dispersent of particles in the matrix [2-5].
The purpose of present work is to investigate the influence of three types of dispersants such as castament FS20, Darvan 7S (polyacrylates), TPP (tripolyphosphate) and microsilica addition on the properties of castables for use in EAF (electric arc farnace) such as flowability, bulk density and cold modulus of rupture and cold crushing strength and slag penetration resistance.

\section{EXPERIMENTAL PROCEDURE}

Tabular alumina, calcined alumina, microsilica, alumina calcium cement contained 17 wt.\% $\mathrm{CaO}$ were used as raw materials. The chemical analyses of the raw materials are listed in Table I. Different batches, with three types of additives were prepared (Tables II, III). Water content was about 5 wt.\%. Flowability of castables was measured by using a vibrating flow table immediately after mixing based on JIS [6]. Castables were cured in air at ambient 
Table I - Chemical analysis of the raw materials.

[Tabela I - Análise química da matéria-prima.]

\begin{tabular}{ccccccccc}
\hline \multicolumn{10}{c}{ Composition (wt.\%) } \\
\hline Type & $\mathrm{Al}_{2} \mathrm{O}_{3}$ & $\mathrm{SiO}_{2}$ & $\mathrm{Fe}_{2} \mathrm{O}_{3}$ & $\mathrm{TiO}_{2}$ & $\mathrm{~K}_{2} \mathrm{O}$ & $\mathrm{Na}_{2} \mathrm{O}$ & $\mathrm{MgO}$ & $\mathrm{CaO}$ \\
Tabular alumina & 99.4 & 0.09 & 0.02 & - & - & 0.4 & - & - \\
Calcined alumina & 99.5 & 0.03 & 0.05 & - & - & 0.3 & - & - \\
Spinel ( MAS76) & 75.3 & 0.3 & 0.28 & - & - & - & 23.1 & 0.5 \\
MgO powders & - & - & - & - & - & - & $>99$ & - \\
Cement & 80 & 0.35 & 0.2 & 0.3 & 0.3 & 0.4 & 0.5 & 17.20 \\
Microsilica & 0.7 & 97.5 & 0.3 & - & 0.6 & 0.3 & 0.5 & 0.3 \\
\hline
\end{tabular}

Table II - Additive combination for alumina-spinel castables (wt.\%).

[Tabela II - Combinação de aditivos nos concretos alumina-espinélio (peso\%).]

\begin{tabular}{cccccccccc}
\hline Additive & $\mathrm{A}_{1}$ & $\mathrm{~A}_{2}$ & $\mathrm{~A}_{3}$ & $\mathrm{~A}_{4}$ & $\mathrm{~A}_{5}$ & $\mathrm{~A}_{6}$ & $\mathrm{~A}_{7}$ & $\mathrm{~A}_{8}$ & $\mathrm{~A}_{9}$ \\
Darvan 7S & 0.05 & 0.1 & 0.15 & - & - & - & - & - & - \\
TPP & - & - & - & 0.05 & 0.1 & 0.15 & - & - & - \\
Castament FS20 & - & - & - & - & - & - & 0.05 & 0.1 & 0.15 \\
\hline
\end{tabular}

Table III - Additive combination for alumina-spinel castables (wt.\%).

[Tabela III - Combinação de aditivos para concretos alumina-espinélio (peso\%).]

\begin{tabular}{cccccccccc}
\hline Additive & $\mathrm{B}_{1}$ & $\mathrm{~B}_{2}$ & $\mathrm{~B}_{3}$ & $\mathrm{~B}_{4}$ & $\mathrm{~B}_{5}$ & $\mathrm{~B}_{6}$ & $\mathrm{~B}_{7}$ & $\mathrm{~B}_{8}$ & $\mathrm{~B}_{9}$ \\
Darvan 7S & 0.1 & 0.1 & 0.1 & - & - & - & - & - & - \\
TPP & - & - & - & 0.1 & 0.1 & 0.1 & - & - & - \\
Castament FS20 & - & - & - & - & - & - & 0.05 & 0.05 & 0.05 \\
\hline
\end{tabular}

temperature for $24 \mathrm{~h}$ and then dried at $110^{\circ} \mathrm{C}$ for at least 16 $\mathrm{h}$ before firing. Specimens 160 by 40 by $40 \mathrm{~mm}$ were cast for measuring the physical properties.

Castable properties are strongly affected by even a little variation in particle size distribution. Castable particle-size distribution (PSD) was calculated from the Andreasen's equation, as follows:

$$
[\mathrm{CPFT} / 100]=(\mathrm{d} / \mathrm{D})^{\mathrm{q}}
$$

CPFT: cumulative percentage of particles finer than the diameter d; d: particle size; D: maximum particle size; q: distribution coefficient. For this work a constant value of $\mathrm{q}=$ 0.29 was used. The $\mathrm{D}$ value was $6.35 \mathrm{~mm}$.

\section{RESULTS AND DISCUSSION}

Fig 1. shows the effect of three types of dispersant on flow values in $\mathrm{Al}_{2} \mathrm{O}_{3}$-spinel castables. Formulation of low-cement castables consists of calcium-aluminate cement, microsilica, afinely milled calcined alumina. Cement will release $\mathrm{Ca}^{2+}$ ions in suspension, these ions will be absorbed by silica surface and cause coagulation deffloculant will place on the surface particles and these particles will get negative charge on the surface and the agglomerate of the system will be broken up. Fig. 1 shows that $\mathrm{Al}_{2} \mathrm{O}_{3}$-spinel castables including castament FS20 have high flow values comparing with castables including Darvan 7S and TPP. Results also show the optimum castament FS20 is $0.05 \mathrm{wt} . \%$. Increase of amount of dispersant by increase of concentration of ions in solution might cause compress of the electric double layer around particles, induce coagulation, and decreases flow values [7].

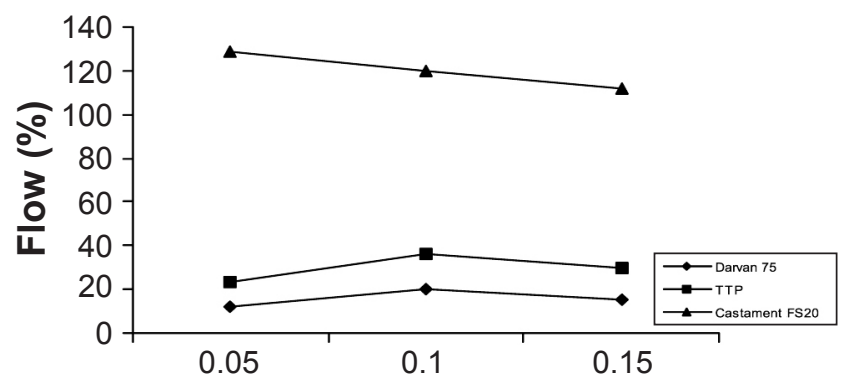

Figure 1: Flow decay curves for the alumina-spinel castables. [Figura 1: Curvas de decaimento da fluidez de concretos aluminaespinélio.]

Castament FS20 belong to polycarboxy late eter (PCE) group which operates on the basic principle of electrosteric 


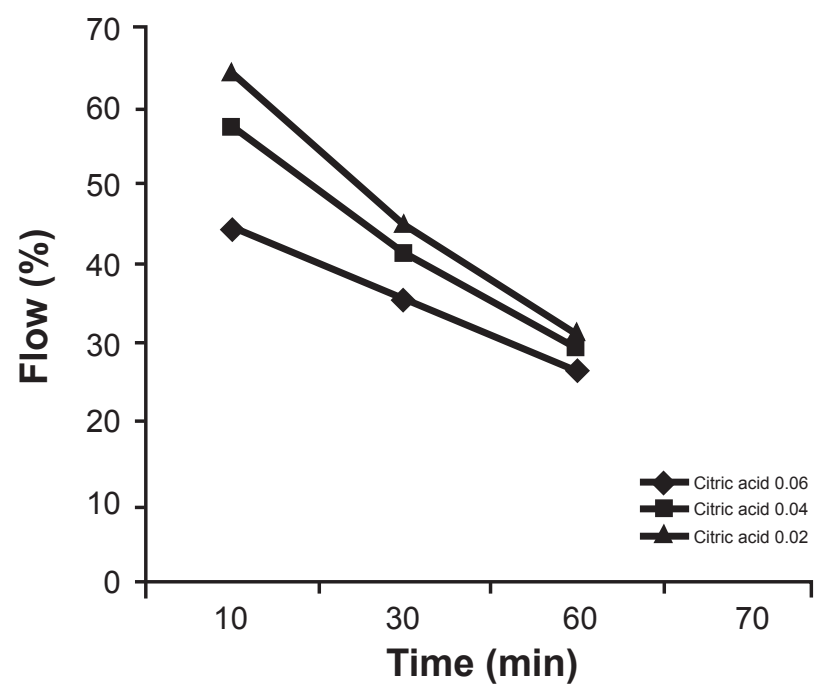

Figure 2: Effect of citric acid on flowability of alumina-spinel castables containing $0.1 \mathrm{wt} \%$ Tpp.

[Figura 2: Efeito do ácido cítrico na fluidez de concreto espinélioalumina contendo 0,1\%peso Tpp.]

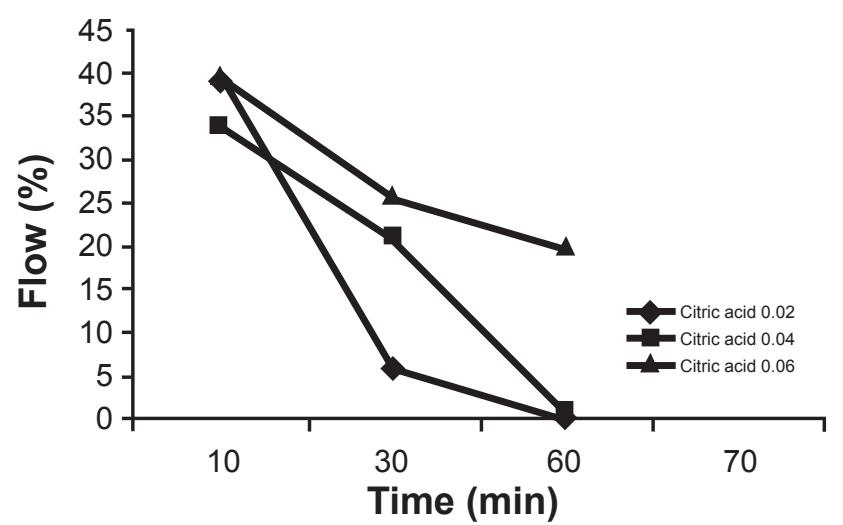

Figure 3: Effect of citric acid on flowability oa alumina-spinel castables containing $0.1 \mathrm{wt} . \%$ Darvan $7 \mathrm{~S}$.

[Figura 3: Efeito do ácido cítrico na fluidez de concreto espinélioalumina contendo 0,1\%peso Darvan.]

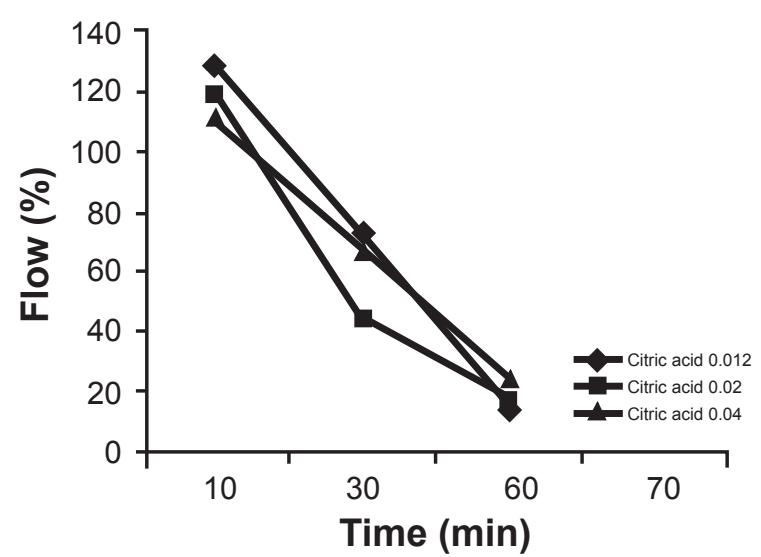

Figure 4: Effect of citric acid on flowability of alumina-spinel castables containing 0.05 wt.\% castament FS20.

[Figura 4: Efeito do ácido cítrico na fluidez de concretos de alumina-espinélio contendo 0,05 peso\% FS20.] stabilization. Electrosteric stabilization is a combination of electrostatic and steric stabilization. Due to these strong electrosteric repulsive forces, the agglomerates of the mineral particles will be thoroughly broken up and the enclosed water in the agglomerates will release. Therefore friction between the mineral particles will be neutralized. These dispersant are very suitable for dispersion and also for deflocculation of $\mathrm{Al}_{2} \mathrm{O}_{3}$-Spinel castables. Another important parameter in designing refractory castables is the control of setting time. Samples without retarders will have shorter working times. Retarders influence on kinetics of hydration by slowing down the dissolution of the anhydrous cement particles. Its mechanism is of inhibiting dissolution by absorption on cement grain and/ or combination with calcium ions [8]. Acid citric will be used as a retarder in this work. This additive possesses carboxylate group $\left(\mathrm{COO}^{-}\right)$. Citrate ions react with the calcium ions and will form calcium citrate which will limit solubility. The activity of $\mathrm{Ca}^{2+}$ suspension and hydrate precipitation will be decreased in suspension [8].

Figs. 2, 3 and 4 show the effect of citric acid on flowability of $\mathrm{Al}_{2} \mathrm{O}_{3}$-spinel castables. Results show that by adding citric acid in castable formulation, flow values will be increased in all of the samples including the three types of dispersants. Results reveal that castable formulation including castament FS20 and acid citric will have good flow properties.

Figs. 5, 6 and 7 show variation cold crushing strength (at $110{ }^{\circ} \mathrm{C}$ and $1500^{\circ} \mathrm{C}$ ) and cold modulus of rupture aluminaspinel castable including Darvan 7S, TPP, castament FS20. Results show the samples including optimum dispersant content have higher cold crushing strength comparing with another samples.

The optimum dispersant will cause the agglomerates of the particles broken up and enclosed water in the agglomerates release and cause increase of flow values and this mode of action cause the best possible rheology of the castables and filling of porosities so the strength of samples will increase.

Tests showed that chemical reaction at elevated

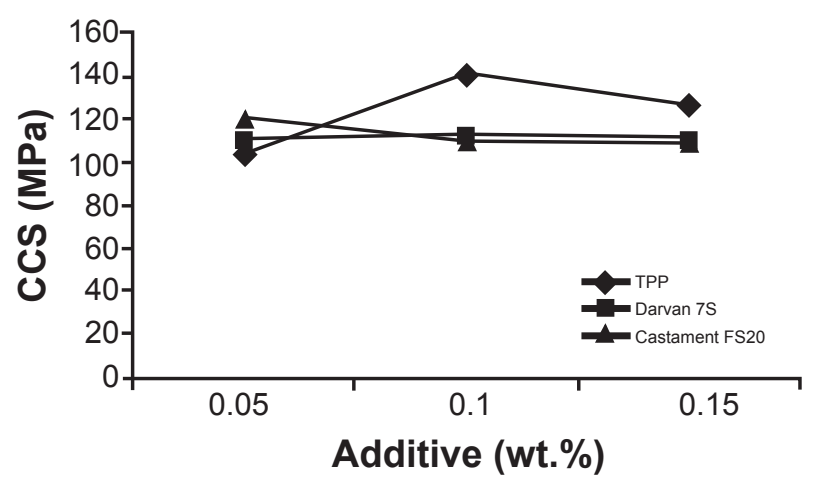

Figure 5: Cold crushing strength alumina- spinel castables at $110^{\circ} \mathrm{C}$. [Figura 5: Resistência de esmagamento a frio de concreto aluminaespinélio a $110^{\circ} \mathrm{C}$.] 


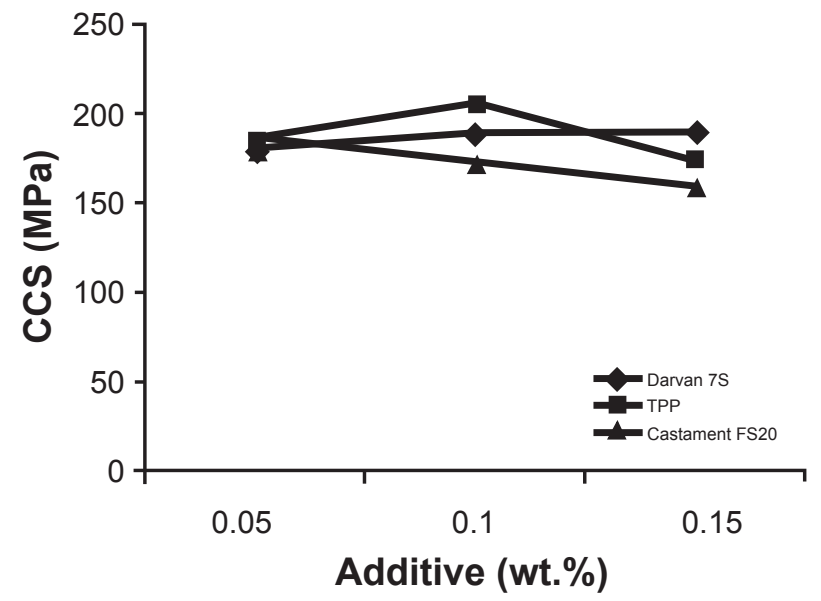

Figure 6: Cold crushing strength alumina-spinel castables after firing at $1500{ }^{\circ} \mathrm{C}$ for $3 \mathrm{~h}$.

[Figura 6: Resistência de esmagamento a frio de concreto aluminaespinélio após tratamento térmico a $1500{ }^{\circ} \mathrm{C}$ durante $3 \mathrm{~h}$.]

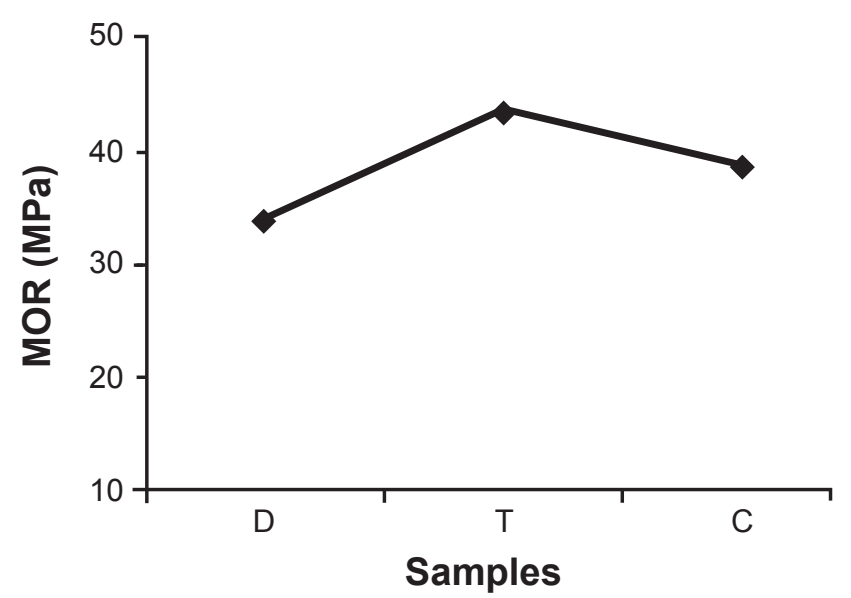

Figure 7: Cold modulus of rupture of alumina-spinel castables after firing at $1500{ }^{\circ} \mathrm{C}$ for $3 \mathrm{~h}$.

(T: 0.1 TPP, D: 0.1 Darvan 7S, C: 0.05 castament FS20).

[Figura 7: Módulo de ruptura a frio de concretos alumia-espinélio após tratamento térmico a $1500^{\circ} \mathrm{C}$ durante 3 h. T: 0,1 TPP, D: 0,1 Darvan 7S, C: 0,05 FS20.]

temperatures plays an important role in changes of physical properties of fired castables with microsilica addition.

Figs. 8 and 9 show that both bulk density and cold crushing strength after drying at $110{ }^{\circ} \mathrm{C}$ increased with addition of microsilica. Because microsilica is the finest particle in the system, then with increasing microsilica addition open porosity decreased. The addition of finegrained powders, such as reactive alumina and microsilica can decrease the mixing water content in the castables. These powders also influence on the better filling of the spaces between the large grains [6]. Then porosity decreased and mechanical strength increased [9].

Fig. 10 shows bulk density increase after firing at $1500{ }^{\circ} \mathrm{C}$ for $3 \mathrm{~h}$. Figs. 11 and 12 show that both cold crushing strength and cold modulus of rupture of the castable after firing at $1500{ }^{\circ} \mathrm{C}$ for $3 \mathrm{~h}$ increased with increasing of microsilica

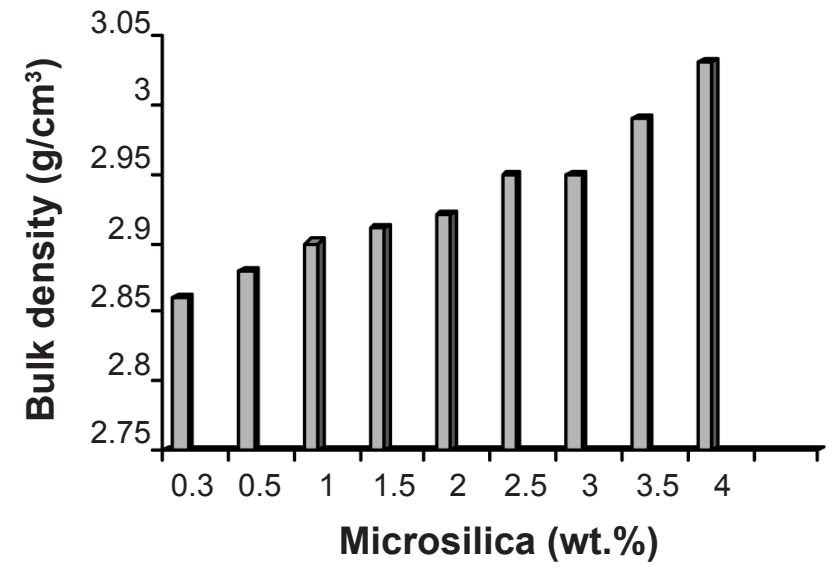

Figure 8: Bulk density alumina-spinel castables at $110^{\circ} \mathrm{C}$.

[Figura 8: Densidade do volume de concretos alumina-espinélio a $110^{\circ} \mathrm{C}$.]

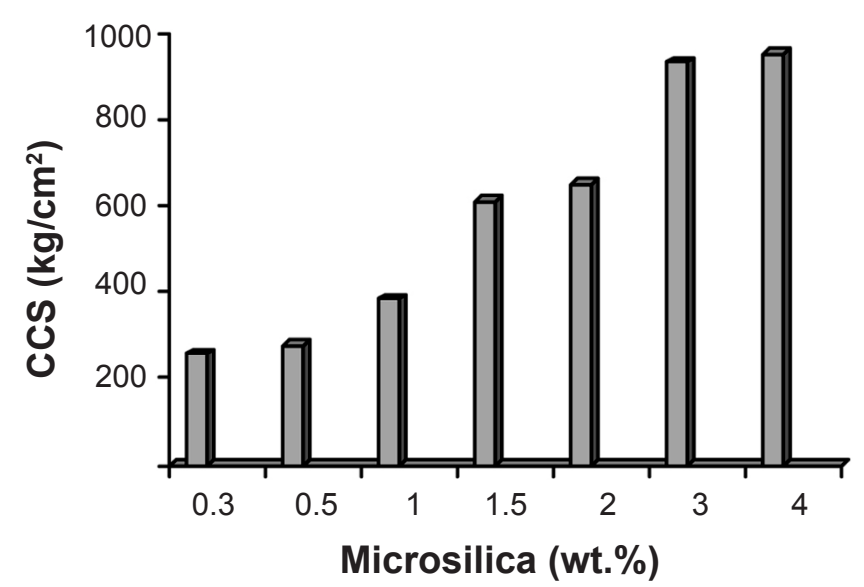

Figure 9: Cold crushing strength alumina-spinel castables at $110{ }^{\circ} \mathrm{C}$. [Figura 9: Resistência ao esmagamento a frio de concretos aluminaespinélio a $110^{\circ} \mathrm{C}$.]

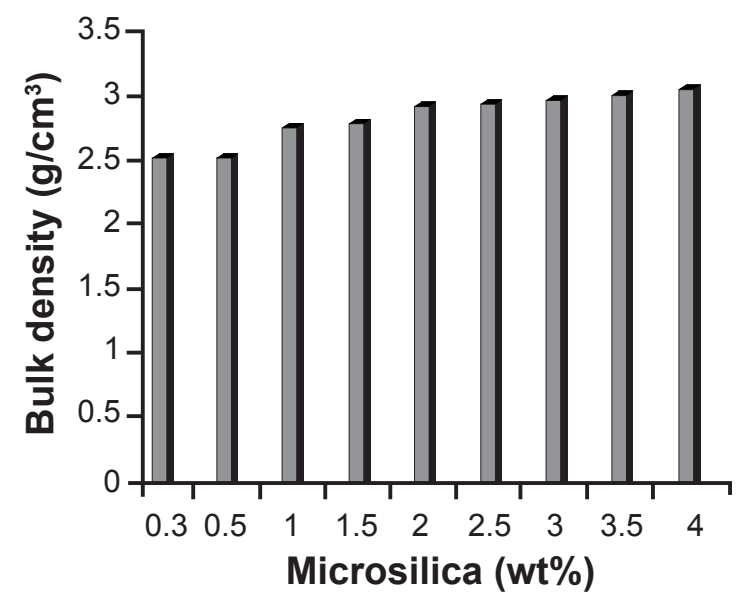

Figure 10: Bulk density alumina-spinel castables at $1500{ }^{\circ} \mathrm{C} / 3 \mathrm{~h}$. [Figura 10: Densidade de concretos alumina-espinélio a $1500^{\circ} \mathrm{C} / 3 \mathrm{~h}$.]

content.

Ko Yung-chao [6] found that the bond linkage between the $\mathrm{CA}_{6}$ and spinel grains in the bonding matrix of aluminaspinel castables is responsible for the increased hot modulus 


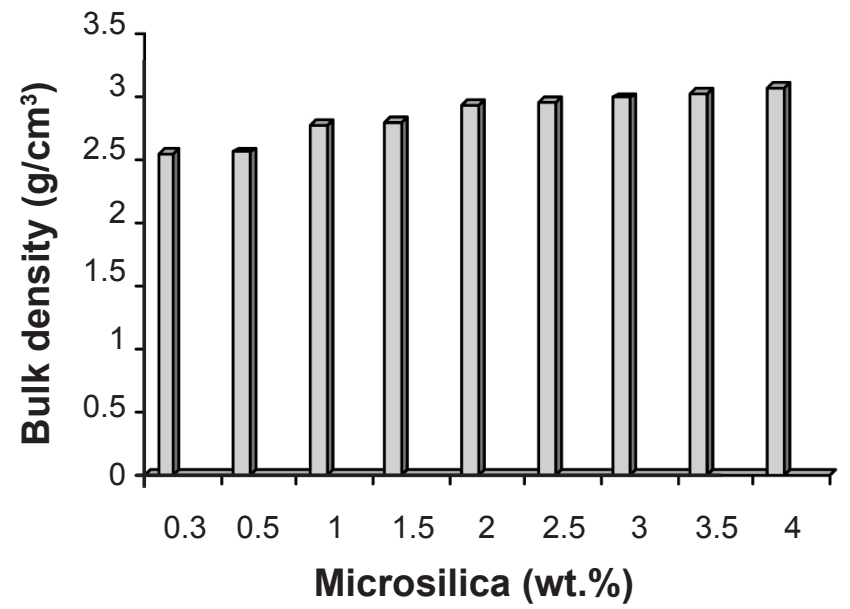

Figure 11: Cold crushing strength alumina-spinel castables after firing at $1500{ }^{\circ} \mathrm{C}$ for $3 \mathrm{~h}$.

[Figura 11: Resistência ao esmagamento a frio de concretos alumina-espinélio após tratamento térmico a $1500^{\circ} \mathrm{C}$ durante $\left.3 \mathrm{~h}.\right]$.

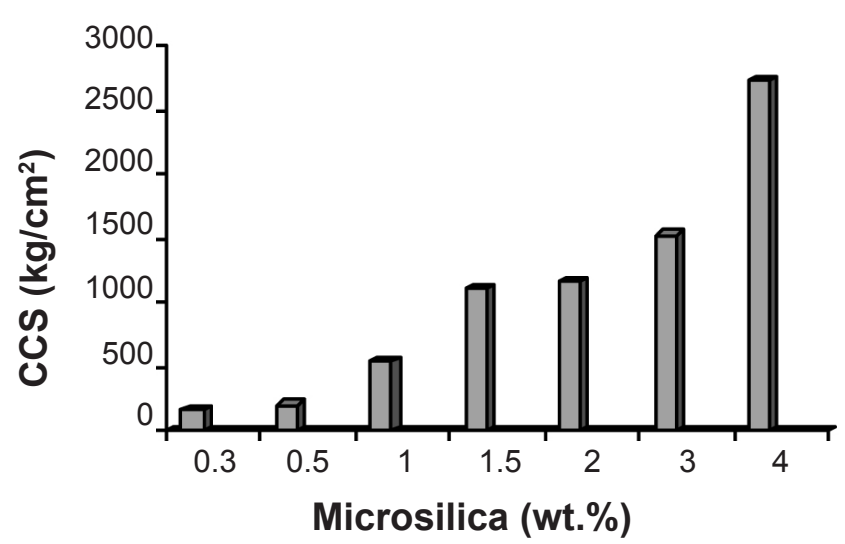

Figure 12: Cold modulus of rupture alumina-spinel castables after firing at $1500{ }^{\circ} \mathrm{C}$ for $3 \mathrm{~h}$.

[Figura 12: Módulo de ruptura a frio de concretos aluminaespinélio após tratamento térmico a $1500^{\circ} \mathrm{C}$ durante 3 h.]

of rupture with both increased $\mathrm{CaO}$ content and temperature from $1300{ }^{\circ} \mathrm{C}$ to $1500{ }^{\circ} \mathrm{C}$. The results show that, porosity decreased with increasing microsilica addition. The trends is also due to increasing liquid phase sintering with increasing microsilica addition. Simonin et al.[10] found that vitreous calsium magnesium aluminosilicate (CMAS) phases exist at $\left(1000{ }^{\circ} \mathrm{C}-1300{ }^{\circ} \mathrm{C}\right)$ and ternary calcium aluminosilicate (CAS) phases exist at low temperatures. These compounds will reduce the temperature of primary liquid phase formation to $1170{ }^{\circ} \mathrm{C}$, which corresponds to the eutetic point of the $\mathrm{Al}_{2} \mathrm{O}_{3}-\mathrm{CaO}-\mathrm{SiO}_{2}$ ternary diagram.

Microsilica reacts with alumina, thus mullite phase has been produced. Mullite, which is formed as a result of silica and alumina reaction, causes the increase of cold resistance (CCS and $\mathrm{CMOR})$.

Figs. 13, 14, 15 show slag penetration resistance increased with increasing microsilica content to $4 \mathrm{wt} \%$. Based on the SEM observations fine particles of $\mathrm{CaO}$ particles transported by the fuel-gas aspiration system and these particles reacted with the alumina and formed

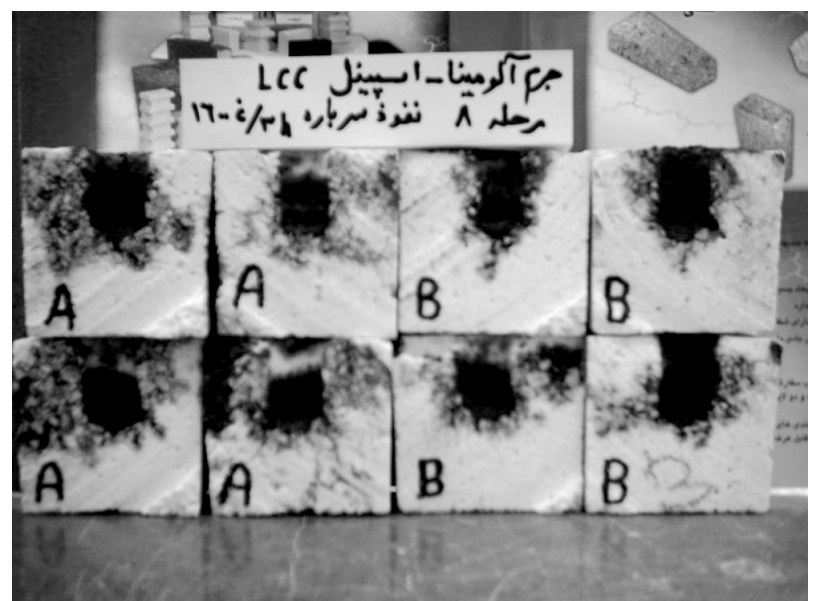

Figure 13: Slag penetration test alumina-spinel castable including (A=2.5, B=3\%wt. microsilica).

[Figura 13: Teste de penetração de escória no concreto aluminaespinélio incluindo $(A=2,5, B=3$ peso $\%$ de microsílica).]

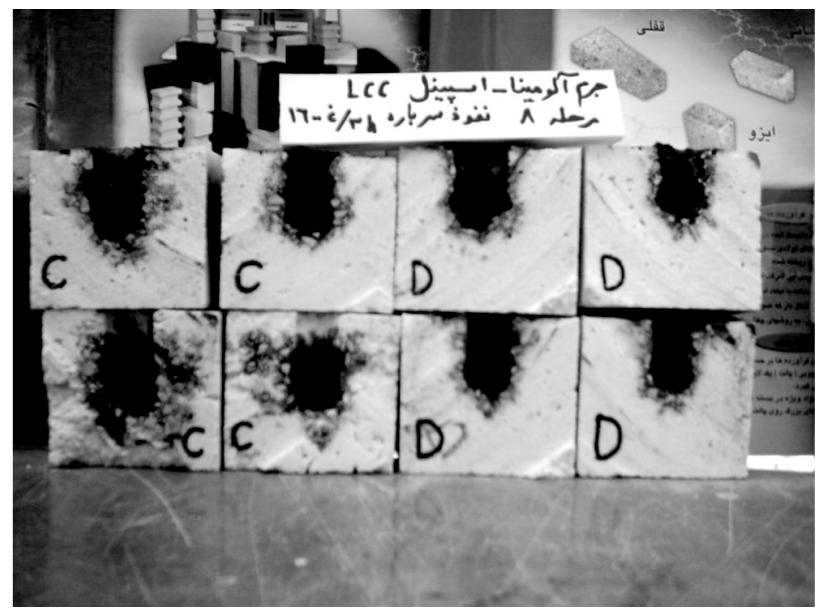

Figure 14: Slag penetration test alumina-spinel castable including $(\mathrm{C}=3.5, \mathrm{D}=4 \%$ wt. microsilica $)$.

[Figura 14: Teste de penetração de escória no concreto aluminaespinélio incluindo $(C=3,5, D=4$ peso $\%$ de microsílica.]

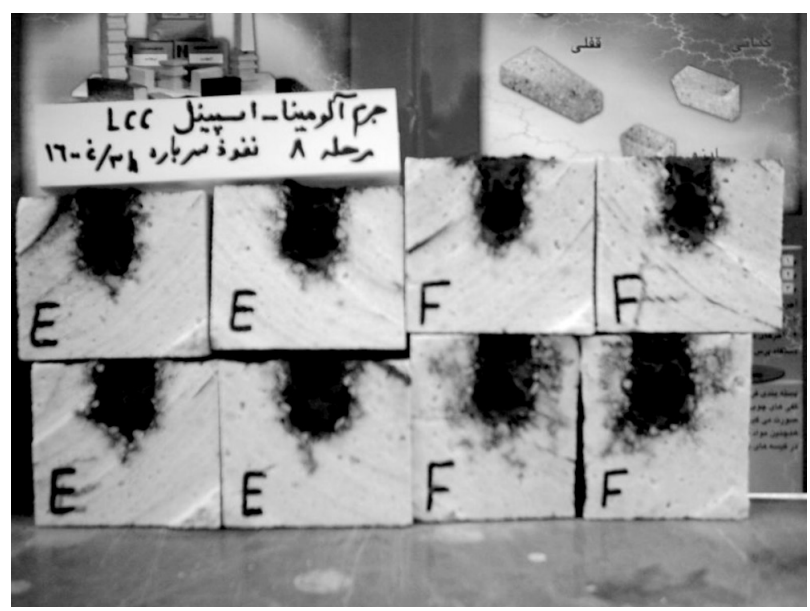

Figure 15: Slag penetration test alumina-spinel castable including ( $\mathrm{E}=4.5, \mathrm{~F}=5 \% \mathrm{wt}$. microsilica).

[Figura 15: Teste de penetração de escória no concreto aluminaespinélio incluindo ( $E=4,5, F=5$ peso\% microsílica.] 


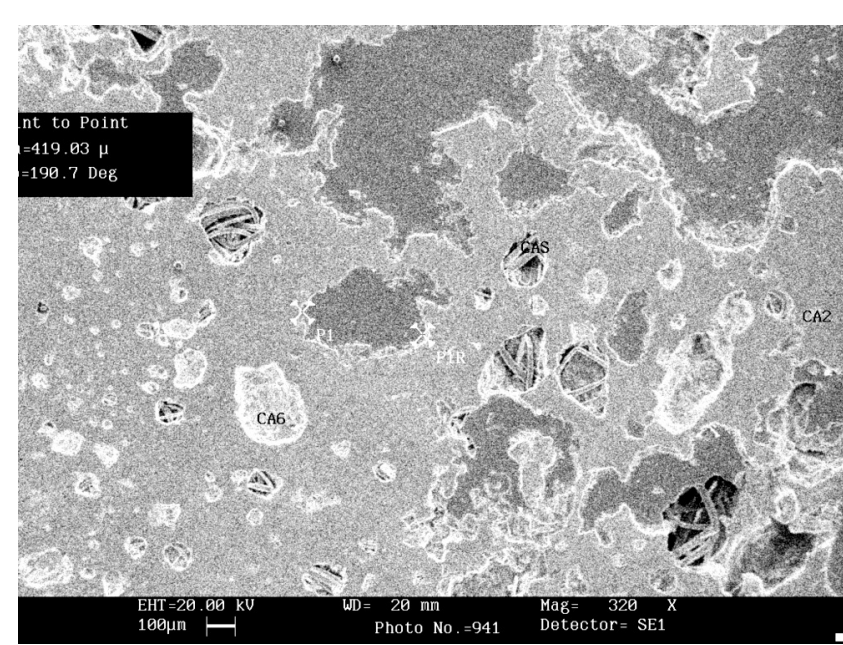

Figure 16: SEM micrograph of the $\mathrm{Al}_{2} \mathrm{O}_{3}$-Spinel castable.

[Figura 16: Micrografia MEV do concreto alumina-espinélio.]

low melting point phases, such as $\mathrm{CA}_{2}$ and $\mathrm{CA}_{6}$ in the hot side of the castable (Fig. 16). In the deeper area of the slag penetration layer, crystal growth of $\mathrm{CaO} \cdot 6 \mathrm{Al}_{2} \mathrm{O}_{3}$ proceeded well, and its crystal growth led to the densification of the castable texture and restrained the slag penetration.

Slag penetration resistance decreased with increasing microsilica addition more than $4 \mathrm{wt} \%$, which can be perhaps attributed to forming cristobalit. Microsilica converted in to cristobalit with a valume expansion and porosity in fired bodies increased. With increasing porosity slag penetration resistance decreased.

\section{CONCLUSIONS}

Alumina-spinel including castament FS20 have higher flow values than castable including Darvan 7S and TPP. Bulk density and cold crushing strength after drying at $110{ }^{\circ} \mathrm{C}$ increased with increasing microsilica. Cold modulus of rupture and cold crushing strength of castables after firing at $1500{ }^{\circ} \mathrm{C}$ for $3 \mathrm{~h}$, increased with increase of microsilica content. Slag penetration resistance increased with increasing microsilica content to 4 wt.\% when the content of microsilica is more than $4 \mathrm{wt} . \%$ slag penetration resistance decrease.

\section{REFERENCES}

[1] L. Baikuan, Unitcer (2001) 320-330.

[2] Y. KO, J. Am. Ceram. Soc. 11, 83 (2000) 2872-74.

[3] S. Yilmaz, Ironmaking and Steelmaking 33, 2 (2006) 151156.

[4] Y. Kutmen. S. Yilmaz, Can. Metallurgical Quarterly 48, 2 (2009) 177-185.

[5] P. Nandi, A. Garg, R. K. Singh, B. D. Chattoraj, Adv. Appl. Ceram. 104, 2 (2005) 83-88.

[6] Y. Ko, Unitcer (1999) 22-25.

[7] K. Wutz, Unitcer (2001) 392-403.

[8] N. Bunt, C. Revais, M. Vialle, Unitcer (1997) 1347-1354 .

[9] B. Myhre, B. Sandberg, Proc. $1^{\text {st }}$ Int. Conf. Monolithic, Tehran, Iran (1997)113-140.

[10] F. Simonin, C. Olagnon, S. Maximilien, J. Am. Ceram. Soc. 10, 83 (2000) 2481-90

(Rec. 14/10/2011, Ac. 25/01/2012) 